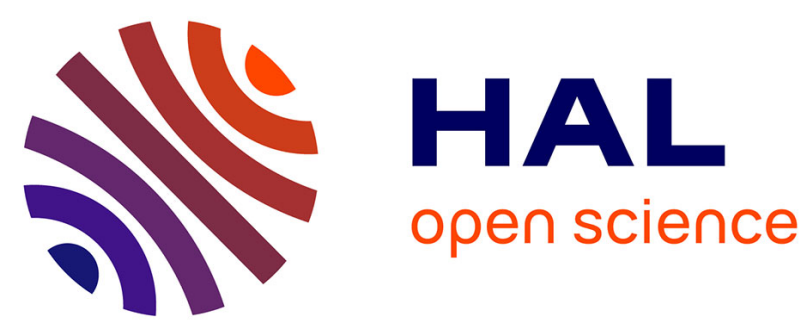

\title{
Unexpected absence of island endemics: Long-distance dispersal in higher latitude sub-Antarctic Siphonaria (Gastropoda: Euthyneura) species
}

Claudio González-Wevar, Nicolás Segovia, Sebastián Rosenfeld, Jaime Ojeda, Mathias Hüne, Javier Naretto, Thomas Saucède, Paul Brickle, Simon Morley, Jean-Pierre Feral, et al.

\section{To cite this version:}

Claudio González-Wevar, Nicolás Segovia, Sebastián Rosenfeld, Jaime Ojeda, Mathias Hüne, et al.. Unexpected absence of island endemics: Long-distance dispersal in higher latitude sub-Antarctic Siphonaria (Gastropoda: Euthyneura) species. Journal of Biogeography, 2018, 45 (4), pp.874-884. 10.1111/jbi.13174 . hal-01698422

\section{HAL Id: hal-01698422 https://hal.science/hal-01698422}

Submitted on 15 May 2018

HAL is a multi-disciplinary open access archive for the deposit and dissemination of scientific research documents, whether they are published or not. The documents may come from teaching and research institutions in France or abroad, or from public or private research centers.
L'archive ouverte pluridisciplinaire HAL, est destinée au dépôt et à la diffusion de documents scientifiques de niveau recherche, publiés ou non, émanant des établissements d'enseignement et de recherche français ou étrangers, des laboratoires publics ou privés. 


\title{
Unexpected absence of island endemics: Long-distance dispersal in higher latitude sub-Antarctic Siphonaria (Gastropoda: Euthyneura) species
}

\author{
Claudio A. González-Wevar ${ }^{1,2}$ | Nicolás I. Segovia ${ }^{2}$ | Sebastián Rosenfeld ${ }^{1,2}$ | \\ Jaime Ojeda $^{1,2}$ | Mathias Hüne ${ }^{2}$ | Javier Naretto ${ }^{2}$ | Thomas Saucède ${ }^{3}$ | \\ Paul Brickle $^{4,5}$ | Simon Morley ${ }^{6}$ | Jean-Pierre Féral ${ }^{7}$ | Hamish G. Spencer ${ }^{8}$ | \\ Elie Poulin ${ }^{2}$
}

\footnotetext{
${ }^{1}$ Laboratorio de Ecosistemas Marinos Antárticos y sub-Antárticos (LEMAS), Universidad de Magallanes, Punta Arenas, Chile

${ }^{2}$ Instituto de Ecología y Biodiversidad (IEB), Universidad de Chile, Santiago, Chile

${ }^{3}$ Biogéosciences, Université de Bourgogne Franche-Comté, UMR CNRS 6282, Dijon, France

${ }^{4}$ South Atlantic Environmental Research Institute (SAERI), Stanley, Falkland Islands

${ }^{5}$ School of Biological Sciences (Zoology), University of Aberdeen, Aberdeen, UK

${ }^{6}$ British Antarctic Survey (BAS), Cambridge, UK

${ }^{7}$ IMBE-Institut Méditerranéen de Biologie et d'Ecologie marine et continentale, UMR 7263, Station Marine d'Endoume, Marseille, France

${ }^{8}$ Department of Zoology, University of Otago, Dunedin, New Zealand

Correspondence

Claudio A. González-Wevar, Laboratorio de Ecosistemas Marinos Antárticos y subAntárticos (LEMAS), Universidad de Magallanes, Punta Arenas, Chile.

Emails: claudio.gonzalez@umag.cl; omeuno01@hotmail.com

Funding information Fondecyt Initiation Project, Grant/Award Number: 11140087; Instituto de Ecología y Biodiversidad, Grant/Award Number: P05-002 ICM, PFB 023; Fondecyt Regular Project, Grant/Award Number: 1151336; IPEV program 1044 Proteker
}

\begin{abstract}
Aim: We assess biogeographical patterns, population structure and the range of species in the pulmonate genus Siphonaria across the sub-Antarctic. We hypothesized that locally endemic cryptic species will be found across the distribution of these direct-developing limpets in the sub-Antarctic.

Location: The sub-Antarctic coasts of the Southern Ocean including South America, the Falkland/Malvinas, South Georgia, Kerguelen and Macquarie Islands.

Methods: Multi-locus phylogenetic reconstructions, mtDNA time-calibrated divergence time estimations and population-based analyses of Siphonaria populations were used at the scale of the Southern Ocean.

Results: We resolve two widely distributed lineages of Siphonaria (S. lateralis and S. fuegiensis) across the sub-Antarctic. MtDNA divergence time estimates suggest that they were separated around 4.0 $\mathrm{Ma}(3.0$ to $8.0 \mathrm{Ma}$ ). Subsequently both species followed different evolutionary pathways across their distributions. Low levels of genetic diversity characterize the populations of both species, reflecting the role of Quaternary glacial cycles during their respective demographic histories, suggesting high levels of dispersal among geographically distant localities.

Main conclusions: Siphonaria lateralis and S. fuegiensis constitute sister and broadly co-distributed species across the sub-Antarctic. Unexpected transoceanic similarities and low levels of genetic diversity in both these direct-developing species imply recurrent recolonization processes through long-distance dispersal to isolated subAntarctic islands. For such groups of Southern Ocean invertebrates, rafting may be more effective for long-distance dispersal than a free-living planktotrophic larval stage. This biogeographical model may explain why many marine species lacking a dispersal phase exhibit broad distributions, low genetic diversity and low population structure over thousands of kilometres.
\end{abstract}

KEYWORDS

Antarctic circumpolar current, direct developers, long-distance dispersal, oceanic biogeography, pulmonate, rafting, Siphonaria, sub-Antarctic 


\section{1 | INTRODUCTION}

Biogeographical mechanisms explaining the distribution of southern temperate taxa have been debated for more than a century (Crame, 1999; Darwin, 1845; Dell, 1972; Knox, 1960; Strugnell, Rogers, Prodöhl, Collins, \& Allcock, 2008). Recently, the literature has been characterized by disagreement over the relative importance of vicariance versus dispersal in the biogeography of the Southern Ocean biota but consensus has emerged about the combined significance of these processes (Clarke, Barnes, \& Hodgson, 2005; Fraser, Nikula, Spencer, \& Waters, 2009; González-Wevar, Nakano, Cañete, \& Poulin, 2010; Gonzalez-Wevar et al., 2017; Moon, Chown, \& Fraser, 2017; Nikula, Fraser, Spencer, \& Waters, 2010; Nikula, Spencer, \& Waters, 2012; Poulin, Gonzalez-Wevar, Díaz, Gérard, \& Hüne, 2014; Saucède, Pierrat, Danis, \& David, 2014; Waters, 2008).

In the marine realm, dispersal plays a central role in the evolution of species with spatially structured populations, resulting in genetic cohesion, global persistence despite local extinction and the tracking of favourable environments in a changing world (Ayre, Minchinton, \& Perrin, 2009; Cowen \& Sponaugle, 2009; Puritz et al., 2017; Ronce, 2007). The presence of pelagic dispersive larval stages in species with low autonomous vagility is often considered a valuable proxy for dispersal potential (Haye, Varela, \& Thiel, 2012; Puritz et al., 2017; Thorson, 1950). Species with free-living planktonic stages (broadcast-spawners) are expected to be more effective dispersers than those lacking larval stages (direct developers) and to exhibit less population differentiation (Haye et al., 2012; Marko, 2004). Nevertheless, meta-analyses and comparative studies, particularly in the Southern Ocean, have challenged such assumptions (Cumming, Nikula, Spencer, \& Waters, 2014; Helmuth, Veit, \& Holberton, 1994; Nikula et al., 2010; Weersing \& Toonen, 2009).

The role of long-distance dispersal by rafting has been especially controversial (Gillespie et al., 2012; Thiel \& Haye, 2006), with its rarity and unpredictability often hindering the development of testable hypotheses (Cowie \& Holland, 2006; Crisp, Trewick, \& Cook, 2011). In the sub-Antarctic, rafting events are mainly associated with buoyant kelps, which facilitate dispersal of different groups from invertebrates (Cumming et al., 2014; Gonzalez-Wevar et al., 2017; Helmuth et al., 1994; Nikula et al., 2010) to non-buoyant kelps (Fraser et al., 2013).

Members of the pulmonate limpet genus Siphonaria occur on rocky intertidal shores worldwide, except in the Arctic. In a recent revision, Dayrat, Goulding, and White (2014) evaluated species richness through molecular and morphological analyses, recording a total of 41 genetic units (species), although many of them were morphologically cryptic and could not be reliably identified by shell characters. Together with this, they showed that no Siphonaria species was broadly distributed across the Indo-West Pacific. Three clades were recorded in southern South America: S. lessonii and two sister cryptic species which had previously been considered as S. lateralis (Dayrat et al., 2014), also known as Kerguelenella lateralis (White \& Dayrat, 2012). These cryptic species showed $6.9 \%$ mtDNA divergence
(Dayrat et al., 2014), and were recognized by Güller, Zelaya, and Ituarte (2015) as S. lateralis and the newly described S. fuegiensis.

Based on morphology, S. lateralis is broadly distributed across the sub-Antarctic from southern South America to Macquarie Island where it is dominant in intertidal rocky environments (Simpson \& Harrington, 1985; Griffiths \& Waller, 2016; Figure 1a). Published mtDNA sequences for $S$. lateralis include individuals from southern South America $(n=10)$ and South Georgia $(n=2)$ (Dayrat et al., 2014; Güller et al., 2015). Genetically identified individuals of $S$. fuegiensis $(n=6)$ have only been recorded from the southern tip of South America (Dayrat et al., 2014; Güller et al., 2015). However, on the basis of subtle differences in shell shape, other specimens have been assigned to $S$. fuegiensis from the Strait of Magellan, the Falkland/Malvinas Islands and Isla de los Estados in southern Argentina (Güller et al., 2015), where the two species are sympatric (Figure 1b).

Like many marine invertebrates in the sub-Antarctic, S. lateralis and probably $S$. fuegiensis are direct developers, with benthic development and low dispersal capacity (Chambers \& Harrington, 1994; Simpson \& Harrington, 1985). Direct development is considered a key evolutionary trait in Southern Ocean marine invertebrates enhancing potential for speciation (Pearse, Mooi, Lockhart, \& Brandt, 2009; Thatje, 2012). Consequently, and as demonstrated in several marine invertebrate groups in this region (Allcock et al., 2011; Janosik, Mahon, \& Halanych, 2011; Leese, Kop, Wägele, \& Held, 2008; Wilson, Schrödl, \& Halanych, 2009), molecular comparisons of widely separated populations might be expected to reveal additional unrecognized cryptic species. Nevertheless, both species are commonly associated with buoyant and broadly dispersing kelps, often being encased in the holdfasts of Durvillaea antarctica (Cumming et al., 2014; Figure 1c-e), and might have a high potential for rafting. As recently demonstrated in crustaceans and gastropods, rafting can be a major biogeographical process shaping patterns of genetic diversity and structure in direct developers across distant areas of the Southern Ocean (Cumming et al., 2014; Nikula et al., 2010, 2012). Such long-distance dispersal could contribute to the broad geographical distribution of Siphonaria at high latitudes.

Here we present phylogenetic and population-based analyses of high-latitude Siphonaria populations from South America, the Falkland/Malvinas Islands, South Georgia, Kerguelen and Macquarie Islands. We provide a clear picture of (1) the evolutionary relationships among the sub-Antarctic Siphonaria species and (2) the geographical distribution of each taxon, to depict biogeographical patterns of the genus at high latitudes. As a consequence of direct development in these higher latitude pulmonates, the main biogeographical patterns in Siphonaria across the Indo-West Pacific (Dayrat et al., 2014), and patterns recorded in Southern Ocean near-shore marine molluscs including Nacella (Gonzalez-Wevar et al., 2017) and Doris (Wilson et al., 2009), we expected to find closely related cryptic species, endemic to each island group. Alternatively, long-distance dispersal mediated by rafting could play a key role in the biogeography of direct developers like Siphonaria 

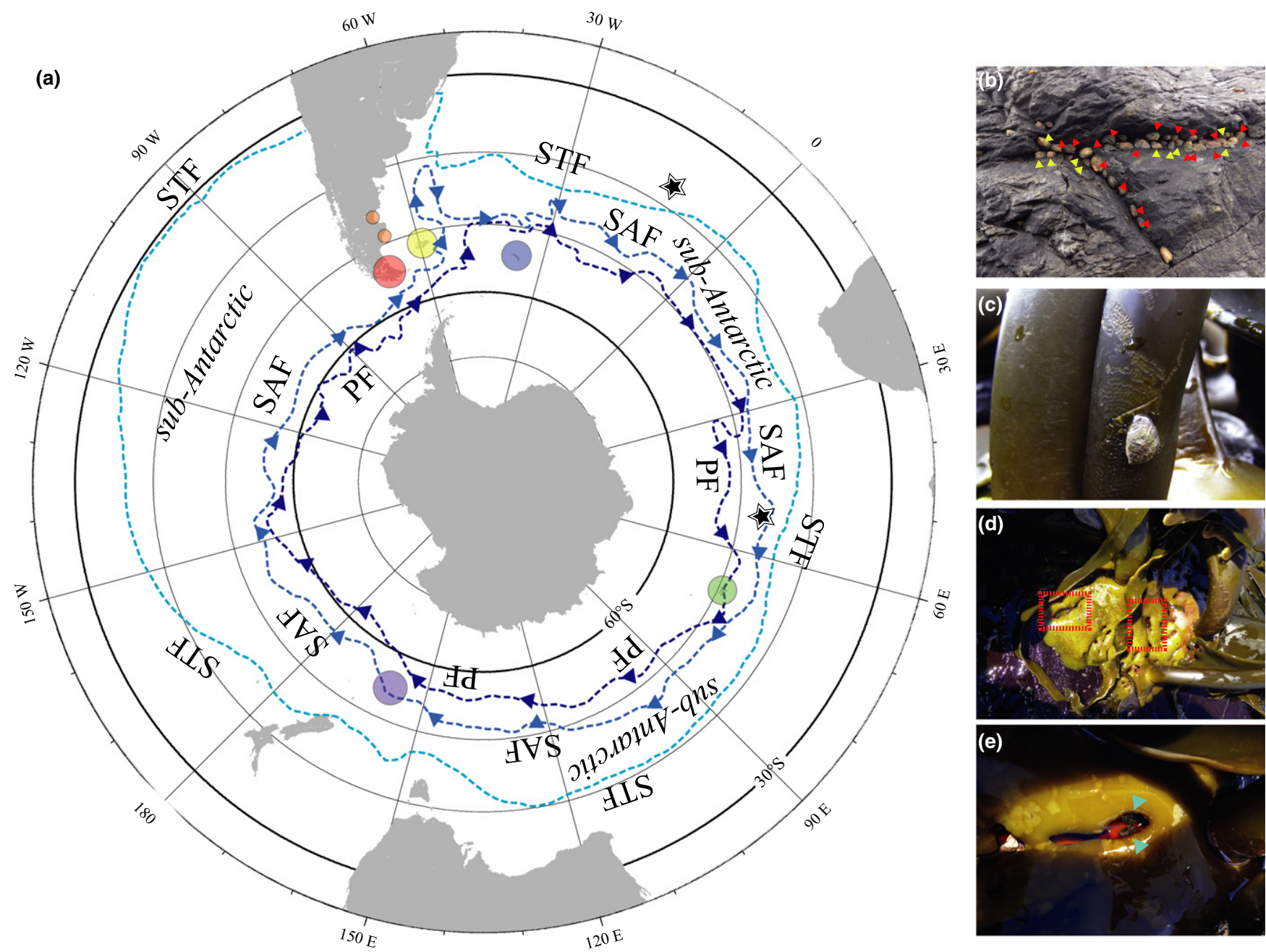

FIGURE 1 (a) Distribution of Siphonaria lateralis around the Southern Ocean showing major oceanographic currents and subdivisions where STF, subtropical front, SAF, sub-Antarctic front, PF, polar front. Stars indicate records of the species (Griffiths \& Waller, 2016) and coloured areas show sampling sites in different provinces of the Southern Ocean (red, Pacific Patagonia; orange, Atlantic Patagonia; blue, South Georgia; yellow, Falkland/Malvinas Islands; green, Kerguelen archipelago; purple, Macquarie Island). (b) Syntopic individuals of $S$. lateralis (red) and $S$. fuegiensis (yellow) recorded at Kerguelen Islands. (c) Individuals of Siphonaria living closely associated with the bull-kelp Durvillaea antartica. (de) Siphonaria individuals living encased in kelp holdfasts at Kerguelen archipelago

permitting a broad distribution of its representatives across the sub-Antarctic.

\section{MATERIAL AND METHODS}

\subsection{Sample collection, DNA preparation and sequence editing}

Siphonaria individuals were sampled from around the Southern Ocean (Figure 1; Figure S1 in Appendix S1) including Pacific Patagonia (PP), Atlantic Patagonia (AP), the Falkland/Malvinas Islands ( $F I)$, South Georgia (SG), Kerguelen Islands (KI) and Macquarie Island (MI) (Table S1 in Appendix S2). All individuals were identified following Dayrat et al. (2014) and Güller et al. (2015). Whole specimens were fixed in ethanol (95\%) and DNA was extracted from the mantle using standard salting-out methodologies (Aljanabi \& Martinez, 1997).
Universal primers were used to amplify partial fragments of the mitochondrial gene cytochrome c oxidase subunit I (COI) (Folmer, Black, Hoeh, Lutz, \& Vrijenhoek, 1994), the nuclear 28 S rRNA (Littlewood, Curini-Galletti, \& Herniou, 2000) and the internal transcribed spacer region (ITS1 \& ITS2) (Oliverio \& Mariottini, 2001). Sequences for each of the analysed fragments were assembled independently and edited using Genelous 5.1.7 (Kearse et al., 2012). Similarly, alignments and base composition of nucleotide sequences were analysed for each marker separately in MEGA 6.0 (Tamura, Strecher, Peterson, Filipski, \& Kumar, 2013) using MuscLE (Edgar, 2004) with standard settings. Mitochondrial codon usage was determined using the Effective Number of Codons value (ENC; Wright, 1990) using DNASP v5 (Librado \& Rozas, 2009). New high latitude Siphonaria sequences are available at Genbank under the following Accession Numbers: COI (MF651995-MF652021), ITSs (MF652022-MF652042) and 28S rRNA (MF652043-MF652059). 


\section{2 | Phylogenetic reconstructions and divergence time estimates}

Mitochondrial (COI) DNA reconstructions used new and previously published (Dayrat et al., 2014) Siphonaria haplotypes from the subAntarctic. For comparative purposes, we also performed multi-locus phylogenetic reconstructions using mtDNA (COI) and nucDNA (ITS1 \& ITS2) sequences. For this we amplified each marker from at least eight individuals of $S$. lateralis, S. fuegiensis and S. lessonii, and we analysed them together with available sequences from $S$. japonica (Wang, Tsang, \& Dong, 2015). Maximum parsimony (MP), maximum likelihood (ML) and Bayesian analyses (BA) were used to estimate phylogenetic relationships. MP analyses were performed using PAUP * (Swofford, 2002) following González-Wevar et al. (2010). The program JMOdeltest 2 (Darriba, Taboada, Doallo, \& Posada, 2012) was used to select the GTR+I+G (COI) and GTR+G (ITS1 \& ITS2) substitution models for the $\mathrm{ML}$ and $\mathrm{BA} . \mathrm{ML}$ and $\mathrm{BA}$ reconstructions based on mtDNA (COI) and multi-locus data sets were carried out using PhyML (Guindon \& Gascuel, 2003) and MrBAyes v.3.1.2 (Huelsenbeck \& Ronquist, 2001) respectively. Nodal support for MP and ML analyses was inferred from non-parametric bootstrap (BS) using 1,000 pseudo-replicates (Felsenstein, 1981). Bayesian-inference posterior probabilities were estimated using the Metropolis coupled Markov chain Monte Carlo algorithm (MCMC) running four chains for $100 \times 10^{6}$ generations, with trees sampled every 1,000 generations. Stationarity was inferred when the average standard deviation of split frequencies was less than 0.01 (Huelsenbeck \& Ronquist, 2001). The initial $10 \%$ of the trees were discarded (burn-in) and posterior probabilities were estimated as the fraction of trees showing a particular node. Posterior probability density was summarized as a maximum clade credibility tree using TREEANNOTATOR v.1.6.1 (http:// beast.bio.ed.ac.uk/TreeAnnotator) and visualized with FIGTREE v.1.4 (http://tree.bio.ed.ac.uk/software/figtree).

The best fit model for the mtDNA COI data set, a relaxed molecular-clock analysis with an uncorrelated lognormal (ucln) model of evolutionary rate heterogeneity, was implemented using the GTR+I+G substitution model in BEAST v.1.6.2 (Drummond, Suchard, Xie, \& Rambaut, 2012). A birth-death speciation prior was used for branching rates in the phylogeny, four chains were run twice for $100 \times 10^{6}$ generations, and trees were sampled every 1,000 generations. Because of the absence of a clear fossil record in Siphonaria we used a conservative mutation rate (1\%), following previous studies in siphonariids (Teske et al., 2011; Wang et al., 2015). Convergence of model parameters was estimated by plotting the marginal posterior probabilities versus the generations in TRACER V.1.5 (http://beast.bio.e d.ac.uk/Tracer). Effective sample-size values were estimated for each parameter to ensure adequate mixing of the MCMC (ESSs > 1,000).

\section{3 | Estimating levels of genetic diversity and structuring}

Levels of mtDNA genetic polymorphism were determined using standard diversity indices including number of haplotypes ( $k$ ), number of segregating sites $(S)$, haplotype diversity $(H)$, average number of pairwise differences $(\Pi)$ and nucleotide diversity $(\pi)$ for each locality and species with DNASP. Genealogical relationships in sub-Antarctic Siphonaria populations were reconstructed using maximum parsimony networks in HAPVIEW (http://www.cibiv.at/ greg/haploviewer). For comparative purposes, we also reconstructed haplotype networks based on $28 \mathrm{~S}$ rRNA $(n=60)$ and ITS1 \& ITS2 $(n=40)$ sequences, independently. We estimated the levels of mtDNA differentiation following Pons and Petit (1996) through mean pairwise differences $\left(N_{\mathrm{ST}}\right)$ and haplotype frequencies $\left(G_{\mathrm{ST}}\right)$ with ARLEQUIN v. 3.5 (Excoffier, Laval, \& Schneider, 2005). The statistical significance of these analyses was assessed using permutation tests (20,000 iterations). We estimated the levels of mtDNA phylogeographical differentiation between subpopulations using the nearest-neighbor statistic $\left(S_{n n}\right)$ (Hudson, 2000) and its statistical significance was estimated through a permutation test $(10,000$ iterations). We inferred the spatial pattern of COI genetic structure in each species by estimating the number and the composition of groups that were the most differentiated based on sequence data with SAMOVA (Spatial Analysis of Molecular Variance) following Dupanloup, Schneider, and Excoffier (2002).

\section{3 | RESULTS}

Mitochondrial DNA alignment within the clearly resolved Siphonaria Clade A (Dayrat et al., 2014) included 268 variable positions (40.79\%) of which 259 (96.64\%) were parsimony informative. Mitochondrial sequences were A-T rich (65.7\%). In contrast, nuclear $28 \mathrm{~S}$ rRNAs $(n=36)$ and ITSs sequences $(n=40)$ were C-G rich $(55.5 \%$ and $60.7 \%$ respectively). Mitochondrial and nuclear sequences were not saturated at any position. No evidence for mtDNA codon bias was detected $(\mathrm{ENC}=39.70)$.

\section{1 | Phylogenetic reconstructions}

Mitochondrial reconstructions corroborated previous molecular studies in Siphonaria and discriminated major taxonomic lineages within Clade A of Dayrat et al. (2014), with high bootstrap values and posterior probabilities (Figure 2). All the reconstruction methods (MP, $\mathrm{ML}$ and $\mathrm{BA}$ ) and markers showed $\mathrm{S}$. lateralis and $\mathrm{S}$. fuegiensis as sister species (Figure 2 and Figure S2 in Appendix S1). Uncorrected $p$ values between these species are $6.4 \%$ and $3.0 \%$ for COI and ITS (Figure $3 a \& b$ ) respectively. In contrast, $S$. lateralis and $S$. fuegiensis differed by just a single base pair for $28 \mathrm{~S}$ rRNA (Figure 3c), highlighting the low resolution of this marker in siphonariids. Even while COI and ITS registered high levels of genetic divergence ( $>12 \%)$, the $28 \mathrm{~S}$ rRNA recorded only three substitutions between $S$. lessonii and S. fuegiensis/S. lateralis. Divergence time estimates based on mtDNA (COI) sequences, under a 95\% Bayesian confidence credible interval for $\mathrm{BCl}$ for relative divergence times (Figure S3 in Appendix S1), suggest that the separation between $S$. lateralis and $S$. fuegiensis occurred during the Pliocene, $4 \mathrm{Ma}(3-8 \mathrm{Ma})$ 


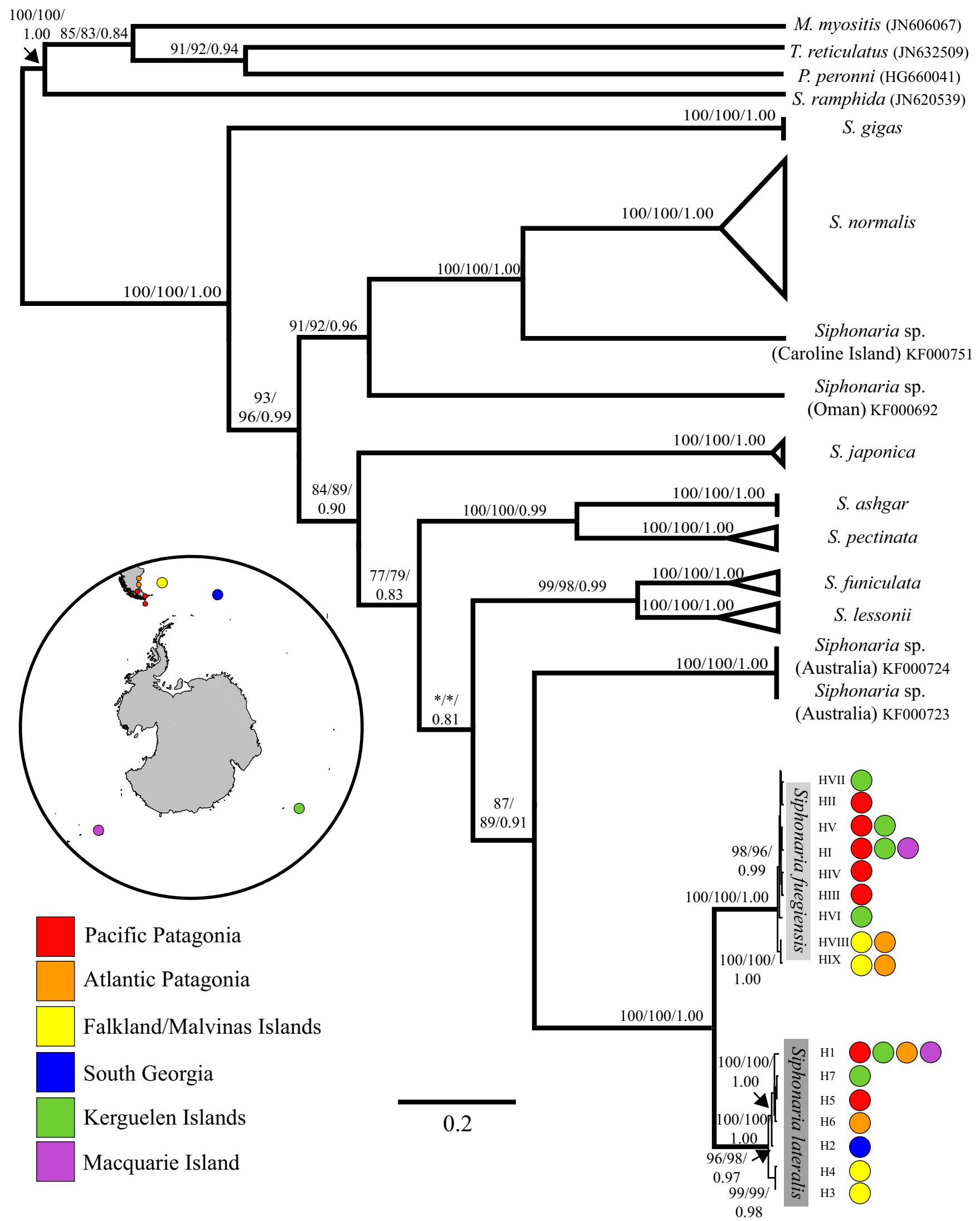

FIGURE 2 Bayesian maximum clade credibility tree of Siphonaria relationships based on mtDNA (COI) sequences with special emphasis on sub-Antarctic individuals collected from around the Southern Ocean. Bootstrap support values (MP and ML) and BPP are shown above the nodes (in that order). Map and colours indicate major sampled areas 
(a)
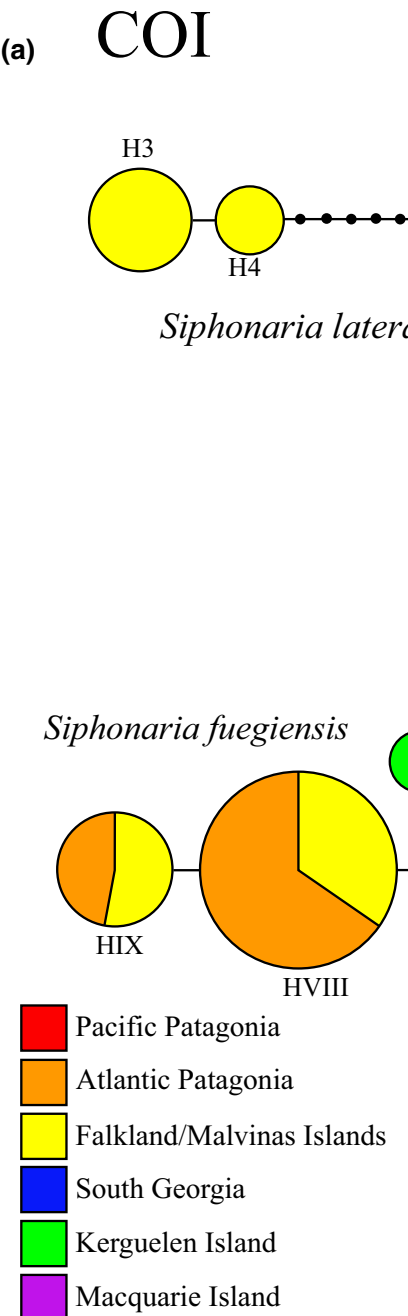

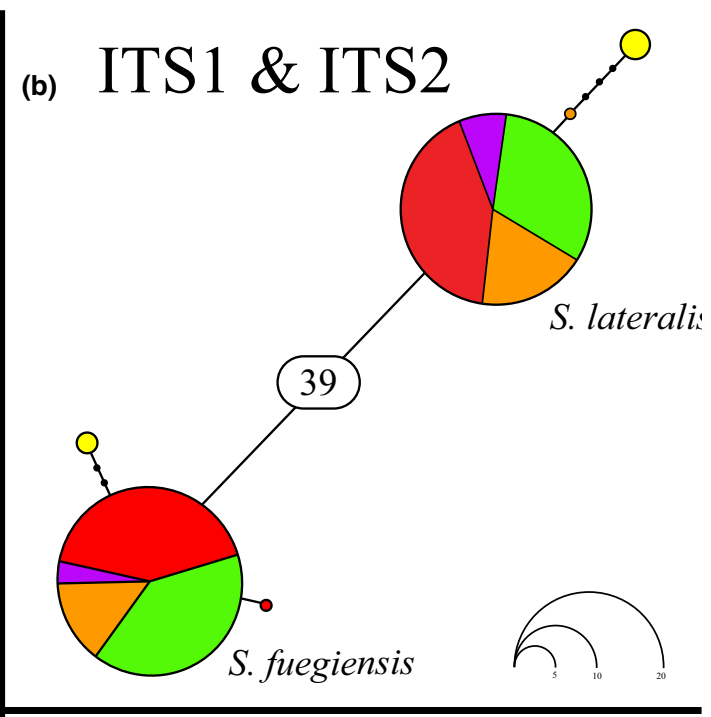

(c) $28 \mathrm{~S}$ rRNA

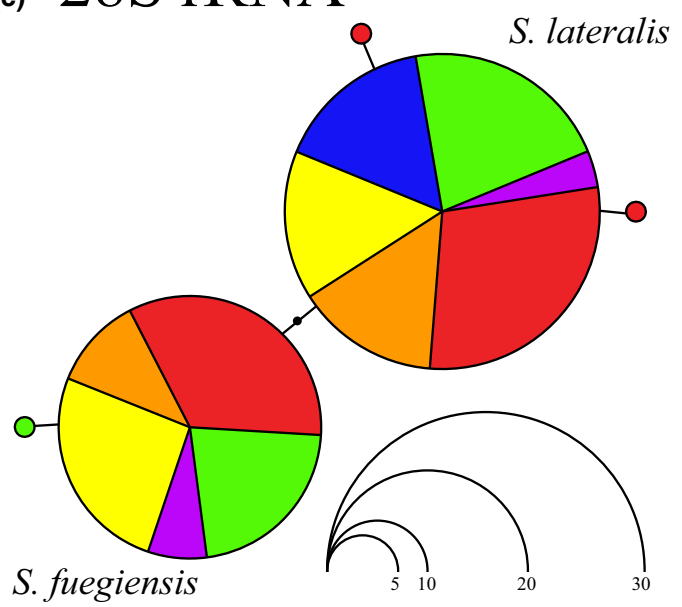

FIGURE 3 (a) mtDNA (COI) Maximum parsimony network including 714 sub-Antarctic individuals of Siphonaria (S. lateralis and S. fuegiensis) collected at different localities in the Southern Ocean. (b) \& (c) nucDNA Maximum parsimony networks based on ITS and 28S rRNA sequences respectively. Each haplotype is represented by a coloured circle indicating the main area where it was collected. The size of the circle is proportional to its frequency in the whole sampling effort

Within S. lateralis, mtDNA reconstructions showed three subclades: (1) Pacific Patagonia (PP) + Atlantic Patagonia (AP) + Kerguelen Islands (KI) + Macquarie Island (MI), (2) South Georgia (SG) and (3) the Falkland/Malvinas Islands (FI) (Figure 2). Within S. fuegiensis, the COI phylogeny showed two subclades: (1) PP+KI+MI and (2) $\mathrm{FI}+\mathrm{AP}$ (Figure 2), being this species absent in SG. Multi-locus reconstructions recovered similar subdivisions within $S$. lateralis and $S$. fuegiensis (Figure S2 in Appendix S1). Considering the low resolution of the $28 \mathrm{~S}$ rRNAs, this marker failed to resolve any grouping within high latitude Siphonaria.

\section{2 | Population-based analyses}

The complete $\mathrm{COI}$ data set for $S$. lateralis and $\mathrm{S}$. fuegiensis included 395 and 319 individuals, respectively, and consisted of 687 nucleotide positions coding for 229 amino acids. Neither indels or stop codons, nor any amino acid change were recorded in the COI data matrix, even when $S$. lateralis and $S$. fuegiensis were separated by a total of 44 substitutions (Figure 3a). ITS sequences for siphonariids $(n=40)$ consisted of 1,282 nucleotide positions. Several indels were recorded in the ITS data matrix and $S$. lateralis and $S$. fuegiensis were separated by 39 substitutions. Finally, $28 \mathrm{~S}$ rRNA sequences included a total of 60 individuals and consisted of 698 nucleotide positions.

Across their respective distributions, very low levels of mtDNA genetic variation characterized the standard diversity indices $(S, H, k$, $\Pi$ and $\pi$ ) in both $S$. lateralis and S. fuegiensis (Tables S2 and S3 in Appendix S2). In fact, 10 out of 14 S. lateralis localities showed no genetic diversity $(H=0)$. Similarly, $H$ indices in $S$. fuegiensis were relatively low and fluctuated between 0.171 (Baie du Prince de Monaco) and 0.605 (Diego Ramírez Island). 
Haplotype networks for S. lateralis and S. fuegiensis showed similar topologies with short genealogies and the presence of specific dominant haplotypes and several endemic ones (Figure 3). In the case of $S$. lateralis, $\mathrm{PP}, \mathrm{AP}, \mathrm{KI}$ and $\mathrm{MI}$ shared a highly dominant haplotype (H1). Individuals from SG showed a single private haplotype $(\mathrm{H} 2)$ separated by a single substitution from $\mathrm{H} 1$. Finally, in the $\mathrm{Fl}$, we recorded two closely related private haplotypes ( $\mathrm{H} 3$ and $\mathrm{H} 4)$ that are separated by seven substitutional steps from $\mathrm{H} 1$ (Figure 3). Similarly, in the case of $S$. fuegiensis, $\mathrm{PP}, \mathrm{KI}$ and $\mathrm{MI}$ shared a dominant $\mathrm{COI}$ haplotype $(\mathrm{HI}$; Figure 3a). A less common haplotype (HV) was recorded in both $\mathrm{PP}$ and $\mathrm{KI}$. In addition, PP and $\mathrm{KI}$ exhibited private medium-frequency haplotypes ( $\mathrm{HII}$ and $\mathrm{HVII}$ respectively). In contrast to $S$. lateralis, the dominant haplotype was not found in AP localities. In fact, $\mathrm{AP}$ and $\mathrm{FI}$ shared two medium-frequency haplotypes (HVIII and HIX) separated by one and two substitutions from $\mathrm{HI}$ respectively (Figure $3 a$ ).

In spite of the low number of individuals analysed, ITS sequences in $S$. lateralis showed the presence of a dominant shared haplotype across PP, AP, KI and MI. Again, individuals from FI showed a different haplotype $(n=3)$ separated by four substitutional steps from the dominant one. Similarly, in the case of $S$. fuegiensis ITS sequences recorded a dominant haplotype broadly distributed in PP, AP, $\mathrm{KI}$ and $\mathrm{MI}$, whereas $\mathrm{FI}$ individuals $(n=2)$ carried a single haplotype separated by two mutational steps from the dominant one (Figure $3 \mathrm{~b}$ ).

\section{3 | Genetic structure in Siphonaria species across the sub-Antarctic}

Mean general values of $\mathrm{COI}$ differentiation measured over 14 populations of $S$. lateralis were high, especially average $G_{S T}(0.239)$ and $N_{\mathrm{ST}}$ (0.259) (Table S4 in Appendix S2). Nevertheless, these results must be regarded with caution because of the presence of endemic haplotypes at SG and FI that strongly separated these localities from the rest. In fact, pairwise $N_{S T}$ and $G_{S T}$ comparisons, $S_{\mathrm{nn}}$ and SAMOVA all clearly discriminated three groups in this species: (1) PP/AP/KI, (2) FI and (3) SG. SAMOVA analyses of $S$. lateralis showed that among-group variation accounts for $95.01 \%$ of the total variance (Table S6 in Appendix S2). Similarly, the nearest-neighbour statistic algorithm recorded high levels of phylogeographical signal $\left(S_{n n}=1.000 p<.0001\right)$ among these SAMOVA's recognized groups.

Within S. fuegiensis, average $G_{S T}(0.229)$ and $N_{S T}(0.300)$ values for $\mathrm{COI}$ were also high as a consequence of the marked differentiation of $\mathrm{Fl} / \mathrm{AP}$ from the remaining populations (Table $\mathrm{S} 5$ in Appendix S2). Pairwise $N_{S T}$ and $G_{S T}$ comparisons, $S_{n n}$ and SAMOVA in $S$. fuegiensis showed two clearly differentiated groups: (1) PP/KI and (2) FI/AP. SAMOVA analyses indicated that variation among these groups accounted for $64.41 \%$ of the total variance (Table S7 in Appendix S2). Similarly, the $S_{\text {nn }}$ statistic recorded high levels of phylogeographical signal $\left(S_{n n}=1.000 p>.0001\right)$ among the recognized SAMOVA groups.

\section{4 | DISCUSSION}

Our results show that two species of pulmonate limpet, Siphonaria lateralis and S. fuegiensis, occur across vast distances of the Southern Ocean, from the Pacific and Atlantic coasts of Patagonia eastward to the Falkland/Malvinas (FI), South Georgia (SG), Kerguelen (KI) and Macquarie Islands (MI). The presence of two such widespread directdeveloping species is a surprise considering that several studies have revealed locally endemic cryptic species on different island groups in the Southern Ocean across different marine invertebrate groups (Gonzalez-Wevar et al., 2017; Janosik et al., 2011; Leese et al., 2008; Wilson et al., 2009), macroalgae (Billard, Reyes, Mansilla, Faugeron, \& Guillemin, 2015; Fraser et al., 2013) and fishes (Dornburg, Federman, Eytan, \& Near, 2016). In these latter cases, there appears to be a limited connectivity among benthic marine populations, regardless of dispersal capacity (Moon et al., 2017). For instance South American and South Georgia populations of the broadcastspawning nemertean Parborlasia corrugatus are genetically distinct, despite the high dispersal capacity (evidenced by population panmixia within the sub-Antarctic and Antarctic regions) (Thornhill, Mahon, Norenburg, \& Halanych, 2008). Similarly, populations of the sea spider Pallenopsis from the Falkland/Malvinas Islands, Antarctica and South America are genetically differentiated (Harder, Halanych, \& Mahon, 2016; Weis et al., 2014).

The vast distributions recorded in both $S$. fuegiensis and S. lateralis, together with the extensive sharing of mitochondrial haplotypes among far-flung populations (Patagonia-Kerguelen-Macquarie) and the low levels of nucleotide polymorphism, imply that both species are good long-distance dispersers. It might seem unlikely that directdeveloping pulmonates would be able to travel across several thousand kilometres of open ocean. Nevertheless, previous studies have demonstrated striking discrepancies between dispersal potential and the observed distribution of direct developers (Ayre et al., 2009). In fact, several direct developing species in the sub-Antarctic including molluscs (Cumming et al., 2014) and crustaceans (Leese, Agrawal, \& Held, 2010; Nikula et al., 2010) exhibit a marked genetic homogeneity across geographically distant areas.

Sub-Antarctic Siphonaria often live closely associated with, and even encased in bull-kelp (Durvillaea antarctica) holdfasts (Morton \& Miller, 1973; Simpson, 1976; E. Poulin \& T. Saucède observations at Kerguelen Islands). Such observations strongly suggest that bull-kelp provides the mechanism for long-distance dispersal as has been inferred for other sub-Antarctic taxa (Cumming et al., 2014; Fraser, Nikula, \& Waters, 2011; Moon et al., 2017; Nikula et al., 2010). As also noted by Griffiths and Waller (2016), the distribution of several sub-Antarctic molluscs (Laevilitorina caliginosa, Nacella and Mytilus) matches the distribution of the bull-kelp. Alternative mechanisms (e.g., rafting on other substrates and anthropogenic introductions) might explain our data, but they seem unlikely (Cumming et al., 2014). We conclude that for species with no dispersive larval stage, long-distance dispersal mediated by rafting is a key biogeographical mechanism explaining the low, or even the absence, of phylogeographical structure across geographically distant areas in the sub- 
Antarctic connected by the flow of the Antarctic circumpolar current (ACC).

Divergence time estimates suggest that the separation of S. lateralis and S. fuegiensis took place during the Pliocene $4 \mathrm{Ma}(3-8 \mathrm{Ma})$ and after that they followed different evolutionary trajectories in sympatry-and even in syntopy-across almost their whole range. At SG only a single species, S. lateralis, was recorded; the apparent absence of $S$. fuegiensis needs to be confirmed. If genuine, this distributional discrepancy could be due to different thermal tolerances between them. At the sampling locations where both species occurred, we noted that $S$. fuegiensis was more prevalent at lower latitudes on the Atlantic coast and in the $\mathrm{FI}$ than S. lateralis, which was more common at higher latitudes of PP and KI. Thus, the absence of S. fuegiensis in SG, the locality of our sampling area with the lowest winter sea-surface temperatures and that was heavily glaciated during the Last Glacial Maximum (LGM) (Hodgson et al., 2014), could be due to a restricted lower thermal tolerance. This hypothesis will be tested by future physiological experiments.

Quaternary glacial processes in the Southern Ocean severely affected the demography of shallow benthic populations as has been demonstrated in several population-based studies (e.g. Allcock \& Strugnell, 2012; Fraser et al., 2009; González-Wevar, Saucède, Morley, Chown, \& Poulin, 2013; González-Wevar et al., 2012, 2016; Nikula et al., 2010; Thornhill et al., 2008). Repeated ice advances and retreats would have generated massive reductions in population sizes (or even local extinctions) and consequent severe declines in genetic diversity. A key signature of populations formerly confined to ancient glacial refugia should be higher and older levels of genetic diversity compared to populations from recently recolonized areas (Allcock \& Strugnell, 2012; González-Wevar et al., 2013; Provan \& Bennett, 2008). Moreover, populations confined to geographically separate refugia are expected to show genetic differentiation due to genetic drift (Provan \& Bennett, 2008). Accordingly, we hypothesize that both species of Siphonaria became extinct at $\mathrm{KI}$ and $\mathrm{MI}$ during the LGM, before they recolonized by rafting during the glacial-interglacial transition from geographically distant refugia, such as southern South America, where glacial impact is known to have been lower, particularly along the Atlantic coast (Rabassa, Coronato, \& Salemme, 2005). Such a process could have occurred several times, during the Plio-Pleistocene, and generated a 'demographic reset' during glacial maxima on the sub-Antarctic islands followed by interglacial recolonization.

Unexpectedly, our results showed that haplotypes of $S$. lateralis from Fl are clearly differentiated ( $\geq 8$ steps away) from those of other localities, including adjacent areas such as Patagonia. Evidence of genetic differentiation between PP and $\mathrm{FI}$ populations has been recorded in crustaceans like Parawaldeckia kidderi (Nikula et al., 2010), and Serolis paradoxa (Leese et al., 2008) and limpets of the genus Nacella (González-Wevar et al., 2012, 2016). Due to their geographical position, the FI were less affected by Quaternary glaciations than other areas of the Southern Ocean (Hodgson et al., 2014). Hence, Siphonaria populations could have persisted and differentiated there during the LGM. In S. fuegiensis, populations from the $\mathrm{FI}$ and those of $\mathrm{AP}$ share two unique haplotypes, suggesting a closer connectivity between the two areas. There is, therefore, a contrast between the two Siphonaria species and their dispersal patterns between these areas. This is an unexpected finding considering the overall morphological and phylogeographical similarities recorded between the two taxa. In S. lateralis, the presence of a fixed SG haplotype indicates that this island may be currently isolated from other areas analysed with the Antarctic Polar Front acting as an oceanographic barrier between the Antarctic and the sub-Antarctic (Poulin et al., 2014). Such a barrier could also explain the absence of $S$. fuegiensis in SG. Alternatively, the stochasticity of rafting could also be used to explain the differences in phylogeographical structure recorded among Patagonia, FI and SG. Just by chance, S. fuegiensis may have rafted between $\mathrm{FI}$ and $\mathrm{AP}$, but $S$. lateralis not. Similarly, by chance, just a single $S$. lateralis haplotype may have reached SG since the last deglaciation but no $S$. fuegiensis individuals successfully colonized this sub-Antarctic island during that period.

\section{5 | CONCLUSIONS}

New biogeographical studies in Southern Ocean near-shore marine benthic invertebrates help us understand the evolution of biota at higher latitudes (Allcock \& Strugnell, 2012; Allcock et al., 2011; Fraser et al., 2009, 2011; Gonzalez-Wevar et al., 2017; Moon et al., 2017; Poulin et al., 2014; Saucède et al., 2014; Waters, 2008). Direct developing species like the pulmonates $S$. lateralis and $S$. fuegiensis show clear evidence of long-distance dispersal across the sub-Antarctic, whereas broadcast-spawning species like Nacella are clearly isolated and separated in the sub-Antarctic islands (GonzalezWevar et al., 2017; González-Wevar et al., 2010). We argue that the geographical distribution of genetic lineages in the Southern Ocean depends on idiosyncratic life-history traits related to the ecology of the species, such as the association with buoyant kelps. In this context, our study suggests that species combining direct development and rafting may be more effective for long-distance dispersal than those species with free-living planktotrophic larval stages. Hence, biogeographical patterns in these organisms also depend on the stochasticity of long-distance dispersal that is mediated by particular vectors. Moreover, in intertidal and shallow water species, the processes of local extinction and recolonization driven by glacial cycles may have prevented speciation across the sub-Antarctic islands.

\section{ACKNOWLEDGEMENTS}

This work was supported by Fondecyt Initiation Project 11140087 and Program FONDAP, Project $\mathrm{N}^{\circ} 15150003$ to C.A.G-W; Projects P05-002 ICM, PFB 023 (Instituto de Ecología y Biodiversidad IEB, Universidad de Chile), and project GAB (ACT172065) to C.A.G-W and E.P. Fondecyt Regular Project 1151336 to E.P and C.A.G-W. The Allan Wilson Centre supported H.G.S. Field access facilities at Kerguelen Archipelago were supported by IPEV program 1044 Proteker to E.P, C.A.G-W, J-P. F. and T.S. We mostly appreciate the 
editorial assistance of Dr. Jon Waters and Dr. Peter Linder for their comments and suggestions. At the same time, four anonymous reviewers helped us significantly to improve the article. This article contributes to the SCAR 'State of Antarctic Ecosystem' (AntEco) programme.

\section{REFERENCES}

Aljanabi, S. M., \& Martinez, I. (1997). Universal and rapid salt-extraction of high quality genomic DNA for PCR-based techniques. Nucleic Acids Research, 25, 4692-4693. https://doi.org/10.1093/na $r / 25.22 .4692$

Allcock, A. L., Barratt, I., Eleaume, M., Linse, K., Norman, M. D., Smith, P. J., ... Strugnell, J. M. (2011). Cryptic speciation and the circumpolarity debate: A case study on endemic Southern Ocean octopuses using the COI barcode of life. Deep-Sea Research Part II, Topical Studies in Oceanography, 58, 242-249. https://doi.org/10.1016/j.dsr2. 2010.05.016

Allcock, A. L., \& Strugnell, J. M. (2012). Southern Ocean diversity: New paradigms from molecular ecology. Trends in Ecology and Evolution, 27, 520-528. https://doi.org/10.1016/j.tree.2012.05.009

Ayre, D. J., Minchinton, T. E., \& Perrin, C. (2009). Does life history predict past and current connectivity for rocky intertidal invertebrates across a marine biogeographic barrier? Molecular Ecology, 18, 18871903. https://doi.org/10.1111/j.1365-294X.2009.04127.x

Billard, E., Reyes, J., Mansilla, A., Faugeron, S., \& Guillemin, M.-L. (2015). Deep genetic divergence between austral populations of the red alga Gigartina skottsbergii reveals a cryptic species endemic to the Antarctic continent. Polar Biology, 38, 2021-2034. https://doi.org/10.1007/ s00300-015-1762-4

Chambers, R. J., \& Harrington, C. D. (1994). A review of larval development in the intertidal limpet genus Siphonaria (Gastropoda: Pulmonata). Journal of Molluscan Studies, 60, 415-423. https://doi.org/ 10.1093/mollus/60.4.415

Clarke, A., Barnes, D. K. A., \& Hodgson, D. A. (2005). How isolated is Antarctica? Trends in Ecology and Evolution, 20, 1-3. https://doi.org/ 10.1016/j.tree.2004.10.004

Cowen, R. K., \& Sponaugle, S. (2009). Larval dispersal and marine population connectivity. Annual Review of Marine Science, 1, 443-466. https://doi.org/10.1146/annurev.marine.010908.163757

Cowie, R. H., \& Holland, B. S. (2006). Dispersal is fundamental to biogeography and the evolution of biodiversity on oceanic islands. Journal of Biogeography, 33, 193-198. https://doi.org/10.1111/j.13652699.2005.01383.x

Crame, J. A. (1999). An evolutionary perspective on marine faunal connection between southernmost South America and Antarctica. Scientia Marina, 63, 1-14. https://doi.org/10.3989/scimar.1999. 63s11

Crisp, M. D., Trewick, S. A., \& Cook, L. G. (2011). Hypothesis testing in biogeography. Trends in Ecology and Evolution, 26, 66-72. https://doi. org/10.1016/j.tree.2010.11.005

Cumming, R. A., Nikula, R., Spencer, H. G., \& Waters, J. M. (2014). Transoceanic genetic similarities of kelp-associated sea slug populations: Long-distance dispersal via rafting? Journal of Biogeography, 41, 2357-2370. https://doi.org/10.1111/jbi.12376
Darriba, D., Taboada, G. L., Doallo, R., \& Posada, D. (2012). jModelTest 2: More models, new heuristics and parallel computing. Nature Methods, 9, 772. https://doi.org/10.1038/nmeth.2109

Darwin, C. R. (1845). Journal of researches into the natural history and geology of the countries visited during the voyage of H.M.S. Beagle round the world, under the Command of Capt. Fitz Roy, R.N., 2nd ed. London: John Murray.

Dayrat, B., Goulding, T. C., \& White, T. R. (2014). Diversity of Indo-West Pacific Siphonaria (Mollusca: Gastropoda: Euthyneura). Zootaxa, 3779, 246-276. https://doi.org/10.11646/zootaxa.3779.2.7

Dell, R. K. (1972). Antarctic benthos. Advances in Marine Biology, 10, $1-$ 216.

Dornburg, A., Federman, S., Eytan, R. I., \& Near, T. J. (2016). Cryptic species diversity in Sub-Antarctic islands: A case study of Lepidonotothen. Molecular Phylogenetics and Evolution, 104, 32-43. https://doi.org/10. 1016/j.ympev.2016.07.013

Drummond, A. J., Suchard, M. A., Xie, D., \& Rambaut, A. (2012). Bayesian phylogenetics with BEAUti and the BEAST 1.7. Molecular Biology and Evolution, 29, 1969-1973. https://doi.org/10.1093/molbev/mss075

Dupanloup, I., Schneider, S., \& Excoffier, L. (2002). A simulated annealing approach to define the genetic structure of population. Molecular Ecology, 11, 2571-2581. https://doi.org/10.1046/j.1365-294X.2002. 01650.x

Edgar, R. C. (2004). MUSCLE: A multiple sequence alignment method with reduced time and space complexity. BMC Bioinformatics, 5, 113. https://doi.org/10.1186/1471-2105-5-113

Excoffier, L., Laval, G., \& Schneider, S. (2005). Arlequin (version 3.0): An integrated software package for population genetics data analysis. Evolutionary Bioinformatics Online, 1, 37-50.

Felsenstein, J. (1981). Evolutionary trees from DNA sequences: A maximum likelihood approach. Journal of Molecular Evolution, 17, 368376. https://doi.org/10.1007/BF01734359

Folmer, O., Black, M., Hoeh, W., Lutz, R., \& Vrijenhoek, R. (1994). DNA primers for amplification of mitochondrial cytochrome $c$ oxidase subunit I from diverse metazoan invertebrates. Molecular Marine Biology and Biotechnology, 3, 294-299.

Fraser, C. I., Nikula, R., Spencer, H. G., \& Waters, J. M. (2009). Kelp genes reveal effects of subantarctic sea during the last glacial maximum. Proceedings of the National Academy of Science of the United States of America, 106, 3249-3253. https://doi.org/10.1073/pnas. 0810635106

Fraser, C. I., Nikula, R., \& Waters, J. M. (2011). Oceanic rafting by a coastal community. Proceedings of the Royal Society of London B: Biological Sciences, 278, 649-655. https://doi.org/10.1098/rspb.2010. 1117

Fraser, C. I., Zuccarello, G. C., Spencer, H. G., Salvatore, L. C., Garcia, G. R., \& Waters, J. M. (2013). Genetic affinities between Trans-Oceanic populations of non-buoyant macroalgae in the high latitudes of the Southern Hemisphere. PLOS ONE, 8, e69138. https://doi.org/10. 1371/journal.pone.0069138

Gillespie, R. G., Baldwin, B. G., Waters, J. M., Fraser, C. I., Nikula, R., \& Roderick, G. K. (2012). Long-distance dispersal: A framework for hypothesis testing. Trends in Ecology and Evolution, 27, 47-56. https://doi.org/10.1016/j.tree.2011.08.009

González-Wevar, C. A., Hüne, M., Cañete, J. I., Mansilla, A., Nakano, T., \& Poulin, E. (2012). Towards a model of postglacial biogeography in shallow marine species along the Patagonian Province: Lessons from the limpet Nacella magellanica (Gmelin, 1791). BMC Evolutionary Biology, 12, 139. https://doi.org/10.1186/1471-2148-12-139

Gonzalez-Wevar, C. A., Hüne, M., Segovia, N. I., Nakano, T., Spencer, H. G., Chown, S. L., .. Poulin, E. (2017). Following the Antarctic circumpolar current: patterns and processes in the biogeography of the limpet Nacella (Mollusca: Patellogastropoda) across the Southern Ocean. Journal of Biogeography, 44, 861-874. https://doi.org/10.1111/jbi. 12908 
González-Wevar, C. A., Nakano, T., Cañete, J. I., \& Poulin, E. (2010). Molecular phylogeny and historical biogeography of Nacella (Patellogastropoda: Nacellidae) in the Southern Ocean. Molecular Phylogenetics and Evolution, 56, 115-124. https://doi.org/10.1016/j.ympev. 2010.02.001

González-Wevar, C. A., Rosenfeld, S., Segovia, N. I., Hüne, M., Gérard, K., Ojeda, J., ... Poulin, E. (2016). Genetics, gene flow, and Glaciation: The case of the South American Limpet Nacella mytilina. PLoS ONE, 11, e0161963. https://doi.org/10.1371/journa I.pone. 0161963

González-Wevar, C. A., Saucède, T., Morley, S. A., Chown, S., \& Poulin, E. (2013). Extinction and recolonization of maritime Antarctica in the limpet Nacella concinna (Strebel, 1908) during the last glacial cycle: Toward a model of Quaternary biogeography in shallow Antarctic invertebrates. Molecular Ecology, 22, 5221-5236. https://doi.org/10. 1111/mec.12465

Griffiths, H. J., \& Waller, C. L. (2016). The first comprehensive description of the biodiversity and biogeography of Antarctic and Sub-Antarctic intertidal communities. Journal of Biogeography, 43, 1143-1155. https://doi.org/10.1111/jbi.12708

Guindon, S., \& Gascuel, O. (2003). A simple, fast, and accurate algorithm to estimate large phylogenies by maximum likelihood. Systematic Biology, 52, 696-704. https://doi.org/10.1080/10635150390235520

Güller, M., Zelaya, D. G., \& Ituarte, C. (2015). How many Siphonaria species (Gastropoda: Euthyneura) live in southern South America? Journal of Molluscan Studies, 82, 80-96.

Harder, A. M., Halanych, K. M., \& Mahon, A. R. (2016). Diversity and distribution within the sea spider genus Pallenopsis (Chelicerata: Pycnogonida) in the Western Antarctic as revealed by mitochondrial DNA. Polar Biology, 39, 677-688. https://doi.org/10.1007/s00300-0151823-8

Haye, P. A., Varela, A. I., \& Thiel, M. (2012). Genetic signatures of rafting dispersal in algal-dwelling brooders Limnoria spp. (Isopoda) along the SE Pacific (Chile). Marine Ecology Progress Series, 455, 111-122. https://doi.org/10.3354/meps09673

Helmuth, B., Veit, R. R., \& Holberton, R. (1994). Long-distance dispersal of a subantarctic brooding bivalve (Gaimardia trapesina) by kelp-rafting. Marine Biology, 120, 421-426. https://doi.org/10.1007/ BF00680216

Hodgson, D. A., Graham, A. G. C., Roberts, S. J., Bentley, M. J., Cofaigh, C. Ó., Verleyen, E., ... Smith, J. A. (2014). Terrestrial and submarine evidence for the extent and timing of the Last Glacial Maximum and the onset of deglaciation on the maritime-Antarctic and sub-Antarctic islands. Quaternary Science Reviews, 100, 137-158. https://doi.org/ 10.1016/j.quascirev.2013.12.001

Hudson, R. R. (2000). A new statistic for detecting genetic differentiation. Genetics, 155, 2011-2014.

Huelsenbeck, J. P., \& Ronquist, F. (2001). MRBAYES: Bayesian inference of phylogenetic trees. Bioinformatics, 17, 754-755. https://doi.org/ 10.1093/bioinformatics/17.8.754

Janosik, A. M., Mahon, A. R., \& Halanych, K. M. (2011). Evolutionary history of Southern Ocean Odontaster sea star species (Odontasteridae; Asteroidea). Polar Biology, 34, 575-586. https://doi.org/10.1007/ s00300-010-0916-7

Kearse, M., Moir, R., Wilson, A., Stones-Havas, S., Cheung, M., Sturrock, S., ... Drummond, A. (2012). Geneious Basic: An integrated and extendable desktop software platform for the organization and analysis of sequence data. Bioinformatics, 28, 1647-1649. https://doi.org/ 10.1093/bioinformatics/bts199

Knox, G. A. (1960). Littoral ecology and biogeography of the Southern Ocean. Proceedings of the Royal Society of London B : Biological Sciences, 152, 577-624. https://doi.org/10.1098/rspb.1960. 0068

Leese, F., Agrawal, S., \& Held, C. (2010). Long-distance island hopping without dispersal stages: Transportation across major zoogeographic barriers in a Southern Ocean isopod. Naturwissenschaften, 97, 583594. https://doi.org/10.1007/s00114-010-0674-y

Leese, F., Kop, A., Wägele, J.-W., \& Held, C. (2008). Cryptic speciation in a benthic isopod from Patagonian and Falkland Island waters and the impact of glaciations on its population structure. Frontiers in Zoology, 5, 1-15.

Librado, P., \& Rozas, J. (2009). DnaSP v5: A software for comprehensive analysis of DNA polymorphism data. Bioinformatics, 25, 1451-1452. https://doi.org/10.1093/bioinformatics/btp187

Littlewood, D. T. J., Curini-Galletti, M., \& Herniou, E. A. (2000). The interrelationships of Proseriata (Platyhelminthes: Seriata) tested with molecules and morphology. Molecular Phylogenetics and Evolution, 16, 449-466. https://doi.org/10.1006/mpev.2000.0802

Marko, P. B. (2004). 'What's larvae got to do with it?' Disparate patterns of post-glacial population structure in two benthic marine gastropods with identical dispersal potential. Molecular Ecology, 13, 597-611. https://doi.org/10.1046/j.1365-294X.2004.02096.x

Moon, K. L., Chown, S. L., \& Fraser, C. I. (2017). Reconsidering connectivity in the sub-Antarctic. Biological Reviews, 92, 2164-2181. https://d oi.org/10.1111/brv.12327

Morton, J. E., \& Miller, M. C. (1973). The New Zealand sea shore. London: Collins.

Nikula, R., Fraser, C. I., Spencer, H. G., \& Waters, J. M. (2010). Circumpolar dispersal by rafting in two subantarctic kelp-dwelling crustaceans. Marine Ecology Progress Series, 405, 221-230. https://doi.org/10. 3354/meps08523

Nikula, R., Spencer, H. G., \& Waters, J. M. (2012). Passive rafting is a powerful driver of transoceanic gene flow. Biology Letters, 9, 1-4.

Oliverio, M., \& Mariottini, P. (2001). Contrasting morphological and molecular variation in Coralliophila meyendorffii (Muricidae, Coralliophilinae). Journal of Molluscan Studies, 67, 243-246. https://doi.org/ 10.1093/mollus/67.2.243

Pearse, J. S., Mooi, R., Lockhart, S. J., \& Brandt, A. (2009). Brooding and species diversity in the Southern Ocean: Selection for brooders or speciation within brooding clades? In I. Krupnik, M. Lang \& S. Miller (Eds.), Smithsonian at the poles: Contribution to international polar year science (pp. 181-196). Washington DC: Smithsonian Institution Scholarly Press. https://doi.org/10.5479/si.097884601X.0

Pons, O., \& Petit, R. J. (1996). Measuring and testing genetic differentiation with ordered Versus unordered alleles. Genetics, 144, 12371245.

Poulin, E., Gonzalez-Wevar, C. A., Díaz, A., Gérard, K., \& Hüne, M. (2014). Divergence between Antarctic and South American marine invertebrates: What molecular biology tells us about Scotia Arc geodynamics and the intensification of the Antarctic Circumpolar Current. Global and Planetary Change, 123, 392-399. https://doi.org/10. 1016/j.gloplacha.2014.07.017

Provan, J., \& Bennett, K. D. (2008). Phylogeographic insights into cryptic glacial refugia. Trends in Ecology \& Evolution, 23, 564-571. https://d oi.org/10.1016/j.tree.2008.06.010

Puritz, J. B., Keever, C. C., Addison, J. A., Barbosa, S. S., Byrne, M., Hart, M. W., ... Toonen, R. J. (2017). Life-history predicts past and present population connectivity in two sympatric sea stars. Ecology and Evolution, 7, 3916-3930. https://doi.org/10.1002/ece3.2938

Rabassa, J., Coronato, A. M., \& Salemme, M. (2005). Chronology of the Late Cenozoic Patagonian glaciations and their correlation with biostratigraphic units of the Pampean region (Argentina). Journal of South American Earth Sciences, 20, 81-103. https://doi.org/10.1016/j.jsame s.2005.07.004

Ronce, O. (2007). How does it feel to be like a Rolling Stone? Ten questions about dispersal evolution. Annual Review of Ecology, Evolution, and Systematics, 38, 231-253. https://doi.org/10.1146/annurev.ecol sys.38.091206.095611

Saucède, T., Pierrat, B., Danis, B., \& David, B. (2014). Biogeographic processes in the Southern Ocean. In C. De Broyer, P. Koubbi, H. J. 
Griffiths, B. Raymond, C. Udekem d'Acoz, deVan Putte A. P., B. Danis, S. Grant, J. Gutt, C. Held, G. Hosie, F. Heutmann, A. Post \& Y. Ropert-Coudert (Eds.), Biogeographic atlas of the Southern Ocean (pp. 456-463). Cambridge: Scientific Committee on Antarctic Research.

Simpson, R. D. (1976). Physical and biotic factors limiting the distribution and abundance of littoral mollusks on Macquarie Island (Sub-Antarctic). Journal of Experimental Marine Biology and Ecology, 21, 11-49. https://doi.org/10.1016/0022-0981(76)90067-8

Simpson, R. D., \& Harrington, S. A. (1985). Egg masses of three gastropods, Kerguelenella lateralis (Siphonariidae), Laevilitorina caliginosa and Macquariella hamiltoni (Littorinidae), from Macquarie Island (subAntarctic). Journal of the Malacological Society of Australia, 7, 17-28.

Strugnell, J. M., Rogers, A. D., Prodöhl, P. A., Collins, M. A., \& Allcock, A. L. (2008). The thermohaline expressway: The Southern Ocean as a centre of origin for deep-sea octopuses. Cladistics, 24, 853-860. https://doi.org/10.1111/j.1096-0031.2008.00234.x

Swofford, D. L. (2002). PAUP*: Phylogenetic analysis using parsimony (* and other methods), Version 4. Sunderland, MA: Sinauer Associations.

Tamura, K., Strecher, G., Peterson, D., Filipski, A., \& Kumar, S. (2013). MEGA6: Molecular evolutionary genetics analysis version 6.0. Molecular Biology and Evolution, 30, 2725-2729. https://doi.org/10. 1093/molbev/mst197

Teske, P. R., Papadopoulos, I., Mmonwa, K. L., Matumba, T. G., McQuaid, C. D., Barker, N. P., \& Beheregaray, L. B. (2011). Climate-driven genetic divergence of limpets with different life histories across a southeast African marine biogeographic disjunction: Different processes, same outcome. Molecular Ecology, 20, 5025-5041. https://d oi.org/10.1111/j.1365-294X.2011.05307.x

Thatje, S. (2012). Effects of capability for dispersal on the evolution of diversity in Antarctic benthos. Integrative and Comparative Biology, 52, 470-482. https://doi.org/10.1093/icb/ics105

Thiel, M., \& Haye, P. A. (2006). The ecology of rafting in the marine environment. III. Biogeographical and evolutionary consequences. Oceanography and Marine Biology: An Annual Review, 44, 323-429. https://doi.org/10.1201/CRCOCEMARBIO

Thornhill, D. J., Mahon, A. R., Norenburg, J. L., \& Halanych, K. M. (2008). Open-ocean barriers to dispersal: A test case with the Antarctic Polar Front and the ribbon worm Parborlasia corrugatus (Nemertea: Lineidae). Molecular Ecology, 17, 5104-5117. https://doi.org/10.1111/j. 1365-294X.2008.03970.x

Thorson, G. (1950). Reproductive and larval ecology of marine bottom invertebrates. Biological Reviews, 25, 1-45. https://doi.org/10.1111/j. 1469-185X.1950.tb00585.x

Wang, J., Tsang, L. M., \& Dong, Y.-W. (2015). Causations of phylogeographic barrier of some rocky shore species along the Chinese coastline. BMC Evolutionary Biology, 15, 114. https://doi.org/10.1186/ s12862-015-0387-0

Waters, J. M. (2008). Driven by the west wind drift? A synthesis of southern temperate marine biogeography, with new directions for dispersalism. Journal of Biogeography, 35, 417-427. https://doi.org/ 10.1111/j.1365-2699.2007.01724.x

Weersing, K., \& Toonen, R. J. (2009). Population genetics, larval dispersal, and connectivity in marine systems. Marine Ecology Progress Series, 393, 1-12. https://doi.org/10.3354/meps08287

Weis, A., Meyer, R., Dietz, L., Dömel, J. S., Leese, F., \& Melzer, R. R. (2014). Pallenopsis patagonica (Hoek, 1881) - a species complex revealed by morphology and DNA barcoding, with description of a new species of Pallenopsis Wilson, 1881. Zoological Journal of the Linnean Society, 170, 110-131. https://doi.org/10.1111/zoj.12097
White, T. R., \& Dayrat, B. (2012). Checklist of genus- and species-group names of the false limpets Siphonaria (Mollusca: Gastropoda: Euthyneura). Zootaxa, 3538, 54-78.

Wilson, N. G., Schrödl, M., \& Halanych, K. M. (2009). Ocean barriers and glaciation: Evidence for explosive radiation of mitochondrial lineages in the Antarctic sea slug Doris kerguelenensis (Mollusca, Nudibranchia). Molecular Ecology, 18, 965-984. https://doi.org/10.1111/j.1365294X.2008.04071.x

Wright, F. (1990). The "effective number of codons" used in a gene. Gene, 87, 23-29. https://doi.org/10.1016/0378-1119(90)90491-9

\section{BIOSKETCH}

Claudio González-Wevar is an evolutionary biologist and a marine biogeographer at Universidad de Magallanes, Chile. His research interest is focused in the understanding of biogeographical patterns and processes in the Southern Ocean near-shore marine benthic fauna. He is currently working in several groups of marine benthic molluscs using molecular analyses at different geographical and temporal scales. He is the South American representative of SCAR (Scientific Committee on Antarctic Research) scientific research programme AntEco (State of the Antarctic Ecosystem).

Author contributions: C.A.G-W., E.P., T.S. and H.G.S. conceived the ideas; C.A.G-W., M.H., J.N., J.O., S.R., P.B., S.M., T.S. and E.P. collected Siphonaria material in different sub-Antarctic provinces. C.A.G-W., J.N., S.R., J.O. and M.H. performed laboratory work supervised by E.P. C.A.G-W., M.H. and N.I.S. performed phylogenetic reconstructions and analysed the data; C.A.G-W., E.P, T.S., S.R., J.N. and H.G.S. interpreted the data; and C.A.G-W, T.S., E.P. and H.G.S. led the writing of the manuscript.

\section{SUPPORTING INFORMATION}

Additional Supporting Information may be found online in the supporting information tab for this article.

How to cite this article: González-Wevar CA, Segovia NI, Rosenfeld S, et al. Unexpected absence of island endemics: Long-distance dispersal in higher latitude sub-Antarctic Siphonaria (Gastropoda: Euthyneura) species. J Biogeogr. 2018;00:1-11. https://doi.org/10.1111/jbi.13174 